\title{
PERIDINIUM QUINQUECORNE VAR. TRISPINIFERUM VAR. NOV. (DINOPHYCEAE) FROM A BRACKISH ENVIRONMENT
}

\author{
José Antolín Aké-Castillo ${ }^{1}$ and Gabriela VÁzQueZ ${ }^{2}$ \\ ${ }^{1}$ Universidad Veracruzana, Instituto de Ciencia Marinas y Pesquerías. \\ Calle Hidalgo 617, Colonia Río Jamapa, 94290 Boca del Río, \\ Veracruz, México. aake@uv.mx \\ .'Instituto de Ecología, A.C. Red de Ecología Funcional. Carretera antigua a \\ Coatepec 351, El Haya, 91070 Xalapa, Veracruz, México.
}

\begin{abstract}
Peridinium quinquecorne is a marine dinoflagellate that bears four characteristic thick spines on the hypotheca. Some specimens, which characteristics of shape, number and arrangement of plates matched those of this species, were found in phytoplankton samples collected at the Sontecomapan coastal lagoon, Mexico, in 1999, 2001, 2003 and 2007. However, the organisms collected bore three spines on the hypotheca instead of four, as described for $P$. quinquecorne. The number of spines and their position on antapical plates were features consistently observed over at least a nine years period. From October 2002 to October 2003, we followed the dynamics of the phytoplankton community at the lagoon and this organism was found only in February and June, when salinity values were lower than 21\%o and temperatures higher than $24.5^{\circ} \mathrm{C}$. In February 2003, this organism reached high cell densities and became the dominant species in the phytoplankton community. Based on observations on the morphology of this dinoflagellate under the light and electron microscopes and its constant possession of only three spines, we propose the new variety name Peridinium quinquecorne var. trispiniferum for this taxon which caused a bloom in this tropical brackish system.
\end{abstract}

Key words: bloom, coastal lagoon, dinoflagellate, Gulf of Mexico, new taxon.

\section{RESUMEN}

Peridinium quinquecorne es un dinoflagelado marino que se caracteriza por la presencia de cuatro espinas conspicuas en la hipoteca. En la laguna de Sontecomapan, en el 
Golfo de México, en muestras de fitoplancton de 1999, 2001, 2003 y 2007, encontramos un organismo cuyas características de forma, número y arreglo de placas coincidieron con las descritas para esta especie. Sin embargo, las poblaciones registradas presentaron sólo tres espinas en la hipoteca en lugar de las cuatro descritas para P. quinquecorne. El número de espinas y su posición en las placas antapicales fue un rasgo constante que se ha observado en un período de nueve años. A partir de octubre de 2002 a octubre de 2003 se estudió la dinámica de la comunidad fitoplanctónica de la laguna de Sontecomapan, y la presencia de este organismo se detectó en los meses de febrero y junio, cuando las salinidades de la laguna estuvieron por debajo de valores de $21 \%$ y a temperaturas mayores a $24.5^{\circ} \mathrm{C}$. En febrero de 2003 alcanzó densidades altas, siendo la especie dominante en la comunidad fitoplanctónica. Basándonos en las observaciones de la morfología de este dinoflagelado en microscopios óptico y electrónico y la posesión de sólo tres espinas como un carácter constante, proponemos la nueva variedad Peridinium quinquecorne var. trispiniferum para este taxon que causó un florecimiento en este sistema tropical salobre.

Palabras clave: dinoflagelado, florecimiento, Golfo de México, laguna costera, taxon nuevo.

\section{INTRODUCTION}

Peridinium quinquecorne Abé is a marine thecate dinoflagellate that bears four characteristic thick spines on the hypotheca (Abé, 1927; Horiguchi \& Pienaar, 1991). Its thecal plate arrangement is pp, x, 3', 2a, 7", 5c, 5"', 2",' 4s, with a large second intercalary plate as a distinctive feature. Horiguchi \& Pienaar (1991) have described some variation in cell shape from diamond to ovoid, and also some variation in the sulcus to antapex length in this species, related to the development of the intercalary bands. The number and pattern of plates, a left-handed, slightly displaced cingulum, and the four antapical spines are consistent features of this species (Madariaga et al., 1989; Horiguchi \& Pienaar, 1991; Trigueros et al., 2000).

Since the description of Peridinium quinquecorne in Japan, its known distribution range has been extended to include the Mediterranean Sea (Halim, 1965; Spatharis et al., 2009), Maribago Bay, Philippinnes (Horstmann, 1980), Northern Spain (Madariaga et al., 1989), South Africa (Horiguchi \& Pienaar, 1991), China's regional seas (Shen et al., 2001), the Mexican Pacific (Cortés-Altamirano, 2002; Okolodkov \& Gárate-Lizárraga, 2006), the Gulf of Mexico (Barón-Campis et al., 2005; Okolodkov et al., 2007) and the Caribbean Sea (Margalef, 1961; Faust et al., 
2005). These records indicate that $P$. quinquecorne lives in temperate and tropical marine waters, although germination of cysts from Finland sediments under experimental conditions, suggests that this species is able to grow under salinities of $6 \%$ and temperatures between 10 and $20^{\circ} \mathrm{C}$ (Pertola et al., 2006).

From an ecological point of view, Peridinium quinquecorne is a significant component of the estuarine phytoplankton causing blooms in the Philippines (Horstmann, 1980), Northern Spain (Madariaga et al., 1989; Trigueros et al., 2000) and China's regional seas (Shen et al., 2001). In the Gernika estuary (Northern Spain), this species is responsible for most of the primary production during the summer and in the same region (Urdaibai estuary), cell densities reached 450 cells ml $^{-1}$ with best growth at temperatures higher than $20{ }^{\circ} \mathrm{C}$ and $29 \%$ salinity (Madariaga et al., 1989; Trigueros et al., 2000). Records of algal blooms caused by this species around the world have become more common recently: Gulf of Mexico (Barón-Campis et al., 2005), Gulf of California (Gárate-Lizárraga \& Muñetón-Gómez, 2008), and the Meditterranean Sea (Spatharis et al., 2009).

Specimens of a dinoflagellate resembling $P$. quinquecorne were repeatedly found in samples collected in different years $(1999,2001,2003$, and 2007) in the Sontecomapan Lagoon, a tropical coastal lagoon located at the southern Gulf of Mexico. Features such as cell form, the number and arrangement of thecal plates and the presence of spines on the hypotheca of these specimens did match those of Peridinium quinquecorne; however, the number of spines did not. This difference was consistently observed in specimens from the Sontecomapan lagoon, where they caused an important bloom in 2003. Morphological studies of dinoflagellate specimens collected in different years showed that the presence of only three spines and their location on the antapical plates were a constant characteristic. Therefore, we propose the description of a new variety with some ecological remarks.

\section{MATERIAL AND METHODS}

The Sontecomapan lagoon is a tropical coastal lagoon permanently connected to the sea (Fig. 1), with a mean depth of $1.5 \mathrm{~m}$ and a high spatial and temporal variation in salinity, ranging from freshwater to marine conditions (Aké-Castillo et al., 1995). The lagoon is fringed by mangrove forest in which Rhizophora mangle L. is the dominant species and contributes a high biomass of litter directly into the lagoon (Aké-Castillo et al., 2006). The phytoplankton community is dominated by diatoms with freshwater, brackish and marine affinities (Aké-Castillo et al., 1995, 
Acta Botanica Mexicana 94: 125-140 (2011)

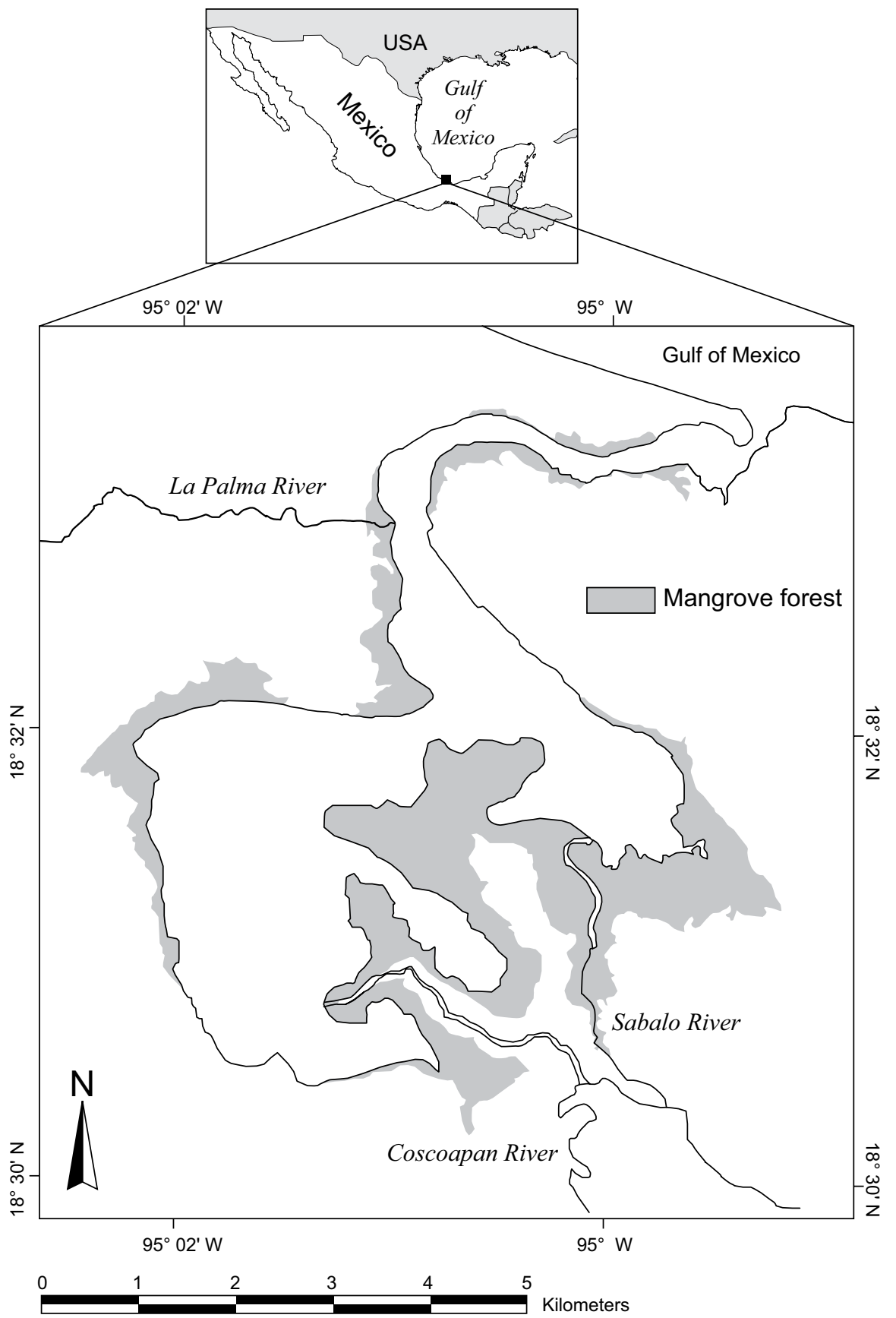

Fig. 1. Study area. 
2004; Aké-Castillo \& Vázquez, 2008). However, during the dry season of the year (i.e., from March to May), the dinoflagellate Ceratium furca var. hircus (Schröder) Margalef is the dominant species (Guerra-Martínez \& Lara-Villa, 1996).

Net and bottle samples (preserved with $4 \%$ final concentration formalin and Lugol-acetate, respectively) that had been collected in June 1999, December 2001, February and June 2003, and March 2007 in the Sontecomapan lagoon, were used to study the dinoflagellate of interest. Bottle samples collected bimonthly (from two depths: surface and close to the bottom) from October 2002 to October 2003 were used to study the dynamics of this dinoflagellate.

Wet mount slides were examined under a light microscope (Nikon Eclipse 80i). Following Lebour (1925), wet mounts containing the dinoflagellate were stained with trypan blue to make the plate pattern evident. The length and width of 30 cells from each sample were measured using an ocular micrometer at $1000 \mathrm{x}$. Drawings were made using a camera lucida and photographs taken using a digital camera Nikon COOLPI4300. Terminology of plate tabulation followed Horiguchi \& Pienaar (1991). Samples with the dinoflagellate were prepared for critical point drying (Lewis et al., 2001) and observed under a scanning electron microscope JEOL-5600.

We used the samples collected from October 2002 to October 2003 for quantitative analysis (Aké-Castillo \& Vázquez, 2008). Cell counts were made applying the Utermöhl's method under an inverted microscope Leica DMIL (Hasle, 1978).

\section{RESULTS}

Description

Peridinium quinquecorne var. trispiniferum Aké-Castillo et Vázquez var. nov.

Cellula solitaria, 17.5-42.5 $\mu \mathrm{m}$ longa, 15-35 $\mu \mathrm{m}$ lata. Tres spinae conspicuae in hypotheca. Chromatophora parva rotunda flavo-viridula numerosa. Formula laminarum pp, x, 3', 2a, 7", 5c, 5'”, 2"'”.

Cells solitary, 17.5-42.5 $\mu \mathrm{m}$ long, 15-35 $\mu \mathrm{m}$ wide. Three conspicuous spines on the hypotheca, which distinguish it from the type variety. Numerous small yellow-greenish chloroplasts. Plate formula pp, x, 3', 2a, 7”, 5c, 5"', 2",". 
Observations

The overall shape of the cell body is ovoid, and divided near the middle by the cingulum (Fig. 6). The epitheca is conical with an evident apical pore (Figs. 6, 7), whereas the hypotheca is rounded and bears three long spines (Figs. 8, 9, 10, 11, 12, $15,16)$. Short spines can be present on the precingular as well as on the postcingular plates (Fig. 9). Plate 1a is pentagonal, located between plates 1', 2', 3", 2' and 2a (Fig. 13). Plate $2 \mathrm{a}$ is large, with seven unequally-sized sides, and the vertices opposite to the apical pore may not be evident, giving the plate a curved appearance (Fig. 14). Intercalary bands are sometimes well developed. Precingular plates are unequal in form and size (Fig. 14). The cingulum is formed by five plates and slightly displaced towards the epitheca. The sulcus does not penetrate into the epitheca and does not reach the antapex (Fig. 15). The three spines on the hypotheca are prominent and straight, rarely one curved. One spine arises from the edge of plate 1"'" and two from opposite edges of plate 2"” (Figs. 15, 16). The numerous chloroplasts are discoid and green-yellowish.

Holotype: Figs. 2-5.

Type locality: Sontecomapan Lagoon, Veracruz, Mexico (18 30' - 18 $34^{\circ}$ N and $\left.94^{\circ} 59^{\prime}-95^{\circ} 04^{\prime} \mathrm{W}\right)$.

Date: 19 February 2003.

Collector: J. A. Aké-Castillo.

Etymology: The variety name makes reference to the three thick spines on the hypotheca.

Habitat: Planktonic, from brackish environments.
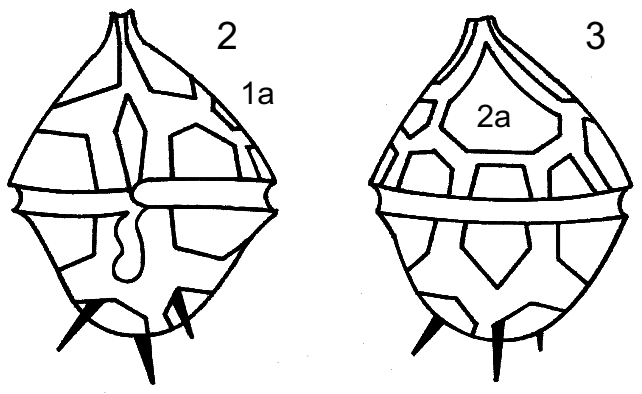

4
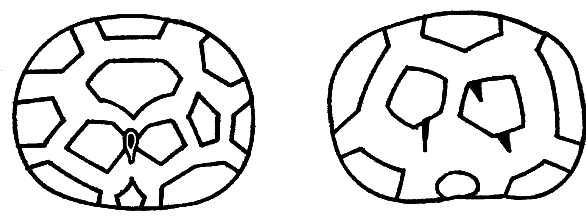

Figs. 2-5. Plate tabulation of Peridinium quinquecorne var. trispiniferum. Fig. 2. Ventral view. Fig. 3. Dorsal view. Fig. 4. Epitheca. Fig. 5. Hypotheca. Scale bar $=20 \mu \mathrm{m}$. 
Ecological observations

Over the period October 2002 to October 2003, Peridinium quinquecorne var. trispinifera was only recorded in the February and June samples. It reached the highest densities in February and the lowest ones in June, when it was only recorded in few samples. Densities ranged from 12 to 4515 cells ml-1 in February, and from 4 to 282 cells ml-1 in June (Table 1). The highest cell density $\left(4515\right.$ cells ml$\left.^{-1}\right)$ was recorded at $10 \%$ salinity and $28.4{ }^{\circ} \mathrm{C}$ temperature.
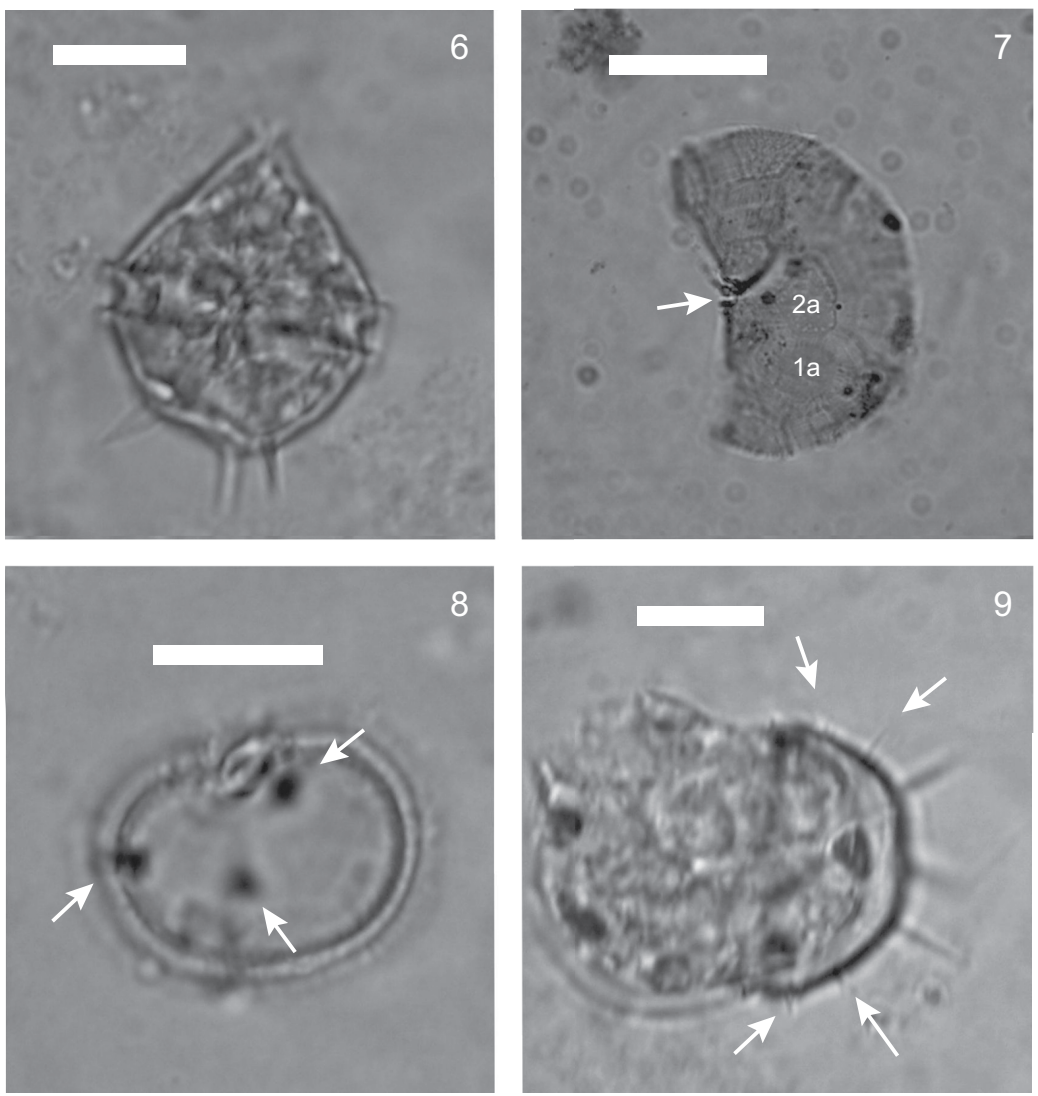

Figs. 6-9. Peridinium quinquecorne var. trispiniferum LM. Fig. 6. Ventral view. Fig. 7. Plate pattern of the epitheca. Note intercalary plates 1a and large plate 2a (indicated by numbers) and the pore plate (arrow). Fig. 8. View of the hypotheca showing three thick spines (arrows) Fig. 9. View of the hypotheca with additional small spines (in focus) on the postcingular plates (arrows). Scale bars $=10 \mu \mathrm{m}$. 

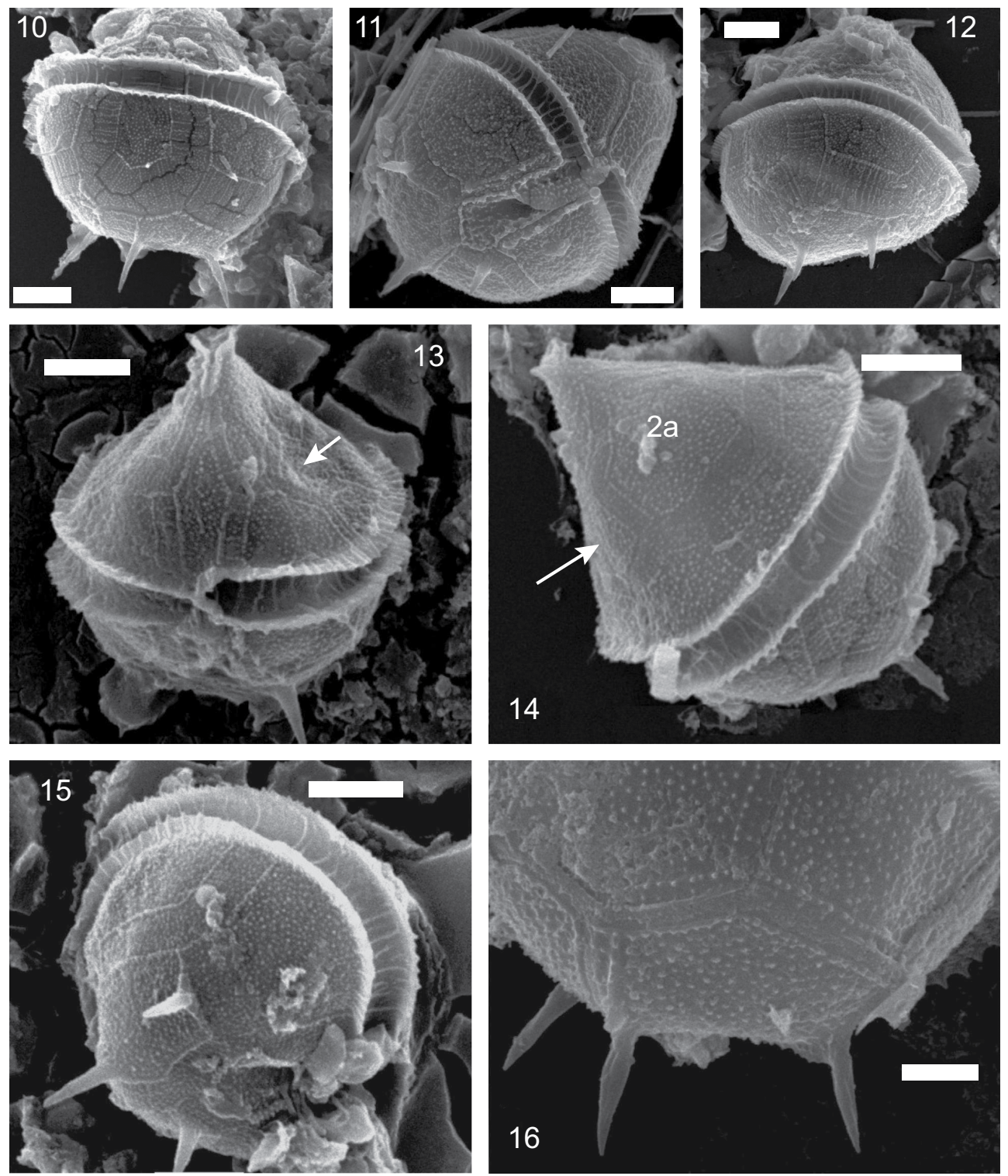

Figs. 10-16. Peridinium quinquecorne var. trispiniferum SEM. Fig. 10. Specimen collected in June 1999. Fig. 11. Specimen collected on December 2001. Fig. 12. Specimen collected in March 2007. Figs. 13-16. Specimens collected in February 2003. Fig. 13. Ventral view. Note plate 1a (arrow). Fig. 14. Dorsal view showing plate 1a (arrow) and the large plate 2a. Fig. 15. Spines position on the hypotheca: one spine on plate 1"'" and two on plate 2"'. Fig. 16. Detail of the spines. Note the position of the spines at the plates' edge. Scale bars $=5 \mu \mathrm{m}$ (Figs. 10-12) or $2 \mu \mathrm{m}$ (Fig. 13). 
Table 1. Descriptive statistics for cell density, salinity and temperature of samples where Peridinium quinquecorne var. trispiniferum occurred over the study period October 2002 October 2003.

\begin{tabular}{lcccccccc}
\hline & \multicolumn{4}{c}{ February $(\mathrm{n}=12)$} & \multicolumn{4}{c}{ June $(\mathrm{n}=7)$} \\
\cline { 2 - 9 } & Mean & Min. & Max. & Std. error & Mean & Min. & Max. & Std. error \\
\hline Cells ml- $^{1}$ & 634.5 & 12 & 4515 & 361.62 & 44.3 & 4 & 282 & 39.72 \\
Salinity \%o & 11.16 & 5 & 21 & 1.55 & 19.14 & 10 & 32 & 2.92 \\
Temperature ${ }^{\circ} \mathrm{C}$ & 26.03 & 24.5 & 28.4 & 0.30 & 30.95 & 29.1 & 32.3 & 0.37 \\
\hline
\end{tabular}

$\mathrm{n}=$ number of samples

\section{DISCUSSION}

Phytoplankton communities of coastal lagoons are complex, as a high diversity of freshwater and marine organisms can co-occur in these environments. As a consequence, confusion about the identification of microalgae may arise. Within dinoflagellates, some genera are distinctively freshwater or marine organisms, but others can be found in both environments (Dodge, 1985; Popovský \& Pfiester, 1990). The genus Peridinium Ehrenberg was split by Gran in 1902 into the genera Peridinium and Protoperidinium Bergh, thus providing a broad separation between the freshwater (Peridinium) and the marine species (Protoperidinium) (Balech, 1974). Thus, the genus Peridinium is commonly regarded to occur only in freshwater environments, but the subdivision into two genera was based on the number of cingular plates (Peridinium bears more than five plates) and, so far, the only species of this genus that is known to occur in marine and brackish environments is Peridinium quinquecorne. In addition, $P$. aciculiferum Lemmermann has been recorded in marine environments in Europe (Popovský \& Pfiester, 1990), and in estuarine environments in the Gulf of Mexico (Steidinger et al., 2009). As this species is characteristic of freshwater environments (Hansen \& Flaim, 2007), its occurrence in marine environments might be the result of river transportation.

Some morphological features -such as cell shape, number and arrangement of plates, and presence of spines on the antapical plates- of the dinoflagellate specimens collected in the Sontecompan Lagoon matched perfectly those of $P$. quinquecorne. However, the number of spines, three in the specimens from the Sontecomapan Lagoon, differed from the typical four of P. quinquecorne (Abé, 1927; Horiguchi \& Piennar, 1986, 1991). 
When Abé described Peridinium quinquecorne in 1927, he based his observations on two individuals found in marine plankton from Mutsu Bay, Japan. He mentioned that this species has four apical, three intercalary and seven precingular plates $\left(4^{l}, 2 \gamma, 7^{a}\right)$. Also mentioned the presence of four spines on the hypotheca, which were commonly curved inwardly or ventrally, and these structures became the most distinctive feature for this species. In 1981 (Abé, 1981), Abé reexamined a few living specimens from which he obtained cultured specimens bearing either complete or incomplete structures and assigned them to P. quinquecorne. Although he pointed out that the study of thecal morphology did not help to establish their taxonomic position, he believed that these specimens belonged to the genus Peridinium. In his description of these specimens, mentioned that some of those presented three spines, and described one small fifth spine between the two median spines. He mentioned that the specimens showed variations in the number of intercalary plates, having either two or three of them, and concluded that the specimens had three apical plates, a varying number of intercalary plates and seven precingular plates. Thus, the new description was quite different from the first one from 1927 in which he mentioned four apical plates. Horiguchi \& Pienaar (1986) studied, for the first time, the ultrastructure of $P$. quinquecorne using electron microscopy and showed micrographs of their specimens. They summarized the tabulation formula based on Abé's latest work as follows: pp, 3', 2-3a, 7', 5',', 2",' and 4-5 prominent antapical spines. However, they pointed out that their specimens always bore four antapical spines. Fukuyo et al. (1990) studied material from Japan and southern Asia and described the tabulation pattern of P. quinquecorne as Po, 3', 2-3a, 7', 5",, 2",", with some variation in the number of spines, having three to five thick spines. One year later, Horiguchi \& Pienaar (1991) studied in detail the micro-morphology of Peridinium quinquercone and described the plate arrangement as follows: pp, x, 3', 2a, 7", 5c, 5',, 2',', 4s and mentioned the location of two spines on plate 1"', and two on plate 2 "," (Table 2).

After this latest description, no other variations in the number of intercalary plates have been reported. Thus, the plate arrangement seems to be a constant characteristic in this species. Halim (1967) and Horstmann (1980) mentioned three intercalary plates in this species. However, we agree with Fukuyo et al. (1990) and Horiguchi \& Sotto (1994) in that Halim's specimens were erroneously identified as Peridinium quinquecorne as the plate tabulation does not correspond to that established by both Abé (1981) and Horiguchi \& Pienaar (1991). Horstmann's species is enigmatic as he based his plate tabulation on Halim's work but his figures do not show the plate pattern. We agree with Horiguchi \& Pienaar (1991) in that Peridinium 
Table 2. Plate formulae and number of spines that have been described for Peridinium quinquecorne.

\begin{tabular}{|c|c|c|c|}
\hline Reference & Plate formula & Number of spines & Location \\
\hline Abé 1927 & $41,2 \gamma, 7 \mathrm{a}$ & 4 & $\begin{array}{l}\text { Hadakaiwa, Mutsu } \\
\text { Bay, Northern Japan }\end{array}$ \\
\hline Halim $1967^{*}$ & 4', 3a, 7, 5'”, 2',' & $1-4$ & $\begin{array}{l}\text { South-east Caribbean } \\
\text { Sea }\end{array}$ \\
\hline Horstman $1980^{* *}$ & $4^{\prime}, 3 a, 7,5^{\prime \prime}, 2^{\prime \prime \prime}$ & 5 or more & $\begin{array}{l}\text { Maribago Bay, } \\
\text { Philippines }\end{array}$ \\
\hline Abé 1981 & 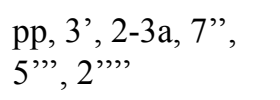 & $3-5$ & $\begin{array}{l}\text { Asamushi, Mutsu } \\
\text { Bay, Northern Japan }\end{array}$ \\
\hline $\begin{array}{l}\text { Horiguchi \& } \\
\text { Pienaar } 1986\end{array}$ & $\begin{array}{l}\text { pp, 3', 2-3a, 7', } \\
5^{\prime \prime \prime, ~ 2, " ' ~(b a s e d ~} \\
\text { on Abé 1981) }\end{array}$ & 4 & $\begin{array}{l}\text { Amanzimtoti and } \\
\text { Palm beach, South } \\
\text { Africa }\end{array}$ \\
\hline Fukuyo et al. 1990 & $\begin{array}{l}\text { Po, X, 3', 2a, 7"', } \\
\text { 5"', 2"', }\end{array}$ & $3-5$ & $\begin{array}{l}\text { Japanese and } \\
\text { southeast Asian } \\
\text { coastal waters }\end{array}$ \\
\hline $\begin{array}{l}\text { Horiguchi \& } \\
\text { Pienaar } 1991\end{array}$ & $\begin{array}{l}\text { pp, x, 3', 2a, 7'”, } \\
5 \mathrm{c}, 5^{\prime \prime}, 2^{\prime \prime},\end{array}$ & $\begin{array}{l}4 \text {, two on each } \\
\text { antapical plate }\end{array}$ & $\begin{array}{l}\text { Natal coast, South } \\
\text { Africa }\end{array}$ \\
\hline $\begin{array}{l}\text { Horiguchi \& Sotto } \\
1994\end{array}$ & $\begin{array}{l}\text { pp, x, 3', 2a, 7', } \\
5 \mathrm{c}, 4 \mathrm{~s}, 5^{\prime \prime}, 2^{\prime \prime \prime},\end{array}$ & 4 , rarely 5 or more & $\begin{array}{l}\text { Maribago Bay, } \\
\text { Philippines }\end{array}$ \\
\hline Trigueros et al. 2000 & $\begin{array}{l}\text { po, x, 3', 2a, 7'”, } \\
5 \mathrm{c}, 4 \mathrm{~s}, 5^{\prime \prime}, 2^{\prime \prime \prime},\end{array}$ & 4 & $\begin{array}{l}\text { Urdaibai estuary, } \\
\text { Northern Spain }\end{array}$ \\
\hline $\begin{array}{l}\text { This work, variety } \\
\text { trispiniferum }\end{array}$ & $\begin{array}{l}\mathrm{pp}, \mathrm{x}, 3^{\prime}, 2 \mathrm{a}, 7^{\prime \prime} \\
5 \mathrm{c}, 5^{\prime \prime}, 2^{\prime \prime \prime}\end{array}$ & $\begin{array}{l}3 \text {, one on first } \\
\text { antapical plate, two on } \\
\text { second antapical plate }\end{array}$ & $\begin{array}{l}\text { Sontecomapan } \\
\text { lagoon, Veracruz, } \\
\text { Gulf of Mexico }\end{array}$ \\
\hline
\end{tabular}

* misidentified, probably Scrippsiella gregaria or Peridinium sociale (see Horiguchi \& Sotto, 1994)

** enigmatic identity as plate pattern can not be resolved from figures (see Horiguchi \& Sotto, 1994)

quinquecorne has only two intercalary plates, and that dorsal view observations have to be made carefully in order to prevent confusing the plate $2 \mathrm{a}$ with an apical plate, following Balech's (1980) criterion, that this plate does not touch the apical pore. Besides Abé's work, we found only one other report (Fukuyo et al., 1990) describing $P$. quinquercone with three spines. These authors pointed out a variation from three to five spines on the hypotheca in specimens from Japan. They showed a 
specimen with five thick spines, four of which were located on the edges of antapical plates, and the fifth one on the suture, close to the second antapical plate (figure C, p. 138, Fukuyo et al., 1990). Their three-spine specimen bears one spine on the first antapical plate, and the other two on the second antapical plate (figure D, p. 138 Fukuyo et al., 1990) just as in our specimens from the Sontecomapan Lagoon. In Maribago Bay, Horstsmann (1980) found specimens of Peridinium quinquecorne bearing five or even more spines on the hypotheca. He showed a picture (figure 4 in Horstmann, 1980) clearly depicting four thick spines that arise from antapical plates, and two smaller spines from the postcingular plates. However, the identity of Hortsmann's specimens has been questioned by Horiguchi \& Sotto (1994) and it is considered enigmatic as the plate pattern described by Horstmann did not fit that of $P$. quinquecorne. The variation in the number of spines mentioned by Halim (1967) does not correspond to P. quinquecorne, as he misidentified his specimens. Other works, where descriptions are provided or photos are shown, have invariably mentioned four spines on the antapical plates (Madariaga et al., 1989; Trigueros et al., 2000; Barón-Campis et al., 2005; Faust et al., 2005; Horiguchi \& Takano, 2006; Gárate-Lizárraga \& Muñetón-Gómez, 2008). Thus, the four spines seem to be the most distinctive feature of $P$. quinquecorne.

The presence of three spines was a consistent feature in our specimens from the Sontecomapan Lagoon, as it was observed over a period of at least nine years. The position of these spines was always the same: one on plate 1"'" and two on opposite edges of plate 2"'" (see figures 10-12, 15 of specimens from different years). A recent bloom of Peridinium quinquecorne in the coastal zone of Veracruz, Gulf of Mexico, involved specimens invariably bearing four spines (Baron-Campis et al., 2005). Thus, our proposal of a new variety is based on the following arguments: 1) populations of the species in Sontecomapan Lagoon having only three antapical spines, 2) permanency over time of this characteristic, and 3) consistency of the spines' location on antapical plates. We believe that we are dealing with a taxon different from the typical P. quinquecorne and, as the presence of three spines had been previously described for this species (Abé, 1981; Fukuyo et al., 1990), we propose the new taxon as an infraspecific name of Peridinium quinquecorne: the variety trispiniferum.

The occurrence of high densities of this organism indicates that we are dealing with a bloom-forming species. Blooms of this new variety occurred at the beginning of the dry season and were followed by the dominance of two other dinoflagellates: Ceratium furca var. hircus (Schröder) Margalef and Prorocentrum cordatum (Ostenfeld) Dodge (Aké-Castillo \& Vázquez, 2008). Temperatures higher than $24.5^{\circ} \mathrm{C}$ 
and salinities lower than $21 \%$ were correlated with high cell densities. Thus, Peridinium quinquecorne var. trispiniferum can be characterized as a mesohaline species with affinity for warm waters. To our knowledge, $P$. quinquecorne has never been reported as a toxic microalga, but it can be considered as a harmful one as it may cause fish mortality by depleting dissolved oxygen (Shamsudin et al., 1996).

The finding of this new bloom-forming taxon in a tropical brackish system makes evident the necessity of further studies on phytoplankton in tropical zones that are known to harbor a high biodiversity. As suggested for other dinoflagellates (Hernández-Becerril \& Alonso-Rodríguez, 2004), variation in microalgae morphology could hide different taxa.

\section{ACKNOWLEDGEMENTS}

The Instituto de Ecología, A. C. provided financial support (projects 902-17 and 902-11-280) for this study. The new taxon was found in samples collected for the Ph. D. dissertation of J. A. Aké-Castillo, who thanks CONACYT for a scholarship (90031) granted during his doctoral studies. This paper was written under agreement MOD-ORD-70-08 PCI-1054-11-08 of the Programa para el Fomento, Desarrollo y Consolidación de Científicos y Tecnólogos CONACYT-UV. Javier Tolome, Ariadna Martínez and Ricardo Madrigal provided field support. Yuri Okolodkov made important suggestions on the manuscript and provided access to basic literature. Takeo Horiguchi kindly provided us with basic literature. We thank Tiburcio Láez for his skilful assistance at the Scanning Electron Microscope Unit, INECOL, A. C., Xalapa. Anonymous reviewers improved the manuscript with their suggestions. We thank Ma. Elena Sánchez-Salazar for reviewing the English translation.

\section{LITERATURE CITED}

Abé, T. H. 1927. Report of the biological survey of Mutsu Bay. 3. Notes on the protozoan fauna of Mutsu Bay. I. Peridiniales. Science Reports of the Tohoku Imperial University. Ser. 4, 2: 383-438.

Abé, T. H. 1981. Studies on the family Peridinidae. An unfinished monograph of the armoured dinoflagellata. Spec. Pub. Seto Mar. Biol. Lab. 6: 1-409.

Aké-Castillo, J. A., M. E. Meave \& D. U. Hernández-Becerril. 1995. Morphology and distribution of species of the diatom genus Skeletonema in a tropical coastal lagoon. Eur. J. Phycol. 30: 107-115. 
Aké-Castillo, J. A., S. L. Guerra-Martínez \& M. E. Zamudio-Reséndiz. 2004. Observation on some species of Chaetoceros (Bacillariophyceae) with reduced number of setae from a tropical coastal lagoon. Hydrobiologia 524: 203-213.

Aké-Castillo, J. A., G. Vázquez \& J. López-Portillo. 2006. Litterfall and decomposition of Rhizophora mangle L. in a coastal lagoon in the southern Gulf of Mexico. Hydrobiologia 559: 101-111.

Aké-Castillo, J. A. \& G. Vázquez. 2008. Phytoplankton variation and its relation to nutrients and allochthonous organic matter in a coastal lagoon on the Gulf of Mexico. Estuar. Coast. Shelf Sci. 78: 705-714.

Balech, E. 1974. El género Protoperidinium Bergh, 1981 (Peridinium Ehr., partim). Rev. Mus. Arg. C. Nat. "B. Rivadavia”, Hidrobiología 4: 1-79.

Balech, E. 1980. On thecal morphology of dinoflagellates with special emphasis on circular and sulcal plates. An. Centro Cienc. del Mar y Limnol. Univ. Nal. Autón. México 7(1): 57-68.

Barón-Campis, S. A., D. U. Hernández-Becerril, N. O. Juárez-Ruíz \& C. Ramírez-Camarena. 2005. Red tide produced by the dinoflagellate Peridinium quinquecorne in Veracruz, Mexico (Oct-Nov. 2002): morphology of the causative agent. Hidrobiológica 15: 73-78.

Cortés-Altamirano, R. 2002. Mareas rojas: Biodiversidad de microbios que pintan el mar. In: Cifuentes-Lemus, J. L. \& J. Gaxiola-López. (eds.). Atlas de la Biodiversidad de Sinaloa. Colegio de Sinaloa, México, D.F. pp. 29-41.

Dodge, J. D. 1985. Marine dinoflagellates of the British Isles. HSMO. London. 303 pp.

Faust, M. A., R. W. Litaker, M. W. Vandersea, S. R. Kibler \& A. P. Tester. 2005. Dinoflagellate diversity and abundance in two Belizean coral-reef mangrove lagoons: a test of Margalef's mandala. Atoll Res. Bull. 534: 103-131.

Fukuyo, Y., T. Hideaki, M. Chihara \& K. Matsuoka. 1990. Red tide organisms in Japan, an illustrated taxonomic guide. U. Rokakuho Publ. Tokyo. 430 pp.

Gárate-Lizárraga, I. \& M. S. Muñetón-Gómez. 2008. Bloom of Peridinium quinquecorne in la Ensenada de la Paz, Gulf of California (July 2003). Acta Bot. Mex. 83: 33-47.

Guerra-Martínez, S. L. \& M. A. Lara-Villa. 1996. "Florecimiento" de Ceratium furca (Peridiniales: Ceratiaceae) en un ambiente salobre: Laguna de Sontecomapan, México. Rev. Biol. Trop. 44: 23-30.

Halim, Y. 1965. Microplancton des eaux égyptiennes. II. Chrysomonadines, Ebriediens et dinoflagellés nouveaux ou d'intérêt biogéographique. Rapp. Proc. Verb. Réun. Comm. Intern. Explor. Sci. Mer Méditerr. 18: 373-379.

Halim, Y. 1967. Dinoflagellates of the South-East Caribbean Sea (East-Venezuela). Int. Rev. Hydrobiol. 52: 701-755.

Hansen, G. \& G. Flaim. 2007. Dinoflagellates of the Trentino Province, Italy. J. Limnol. 66(2): 107-141.

Hasle, G. R. 1978. The inverted-microscope method. In: Sournia, A. (ed.). Phytoplankton manual. United Nations Educational, Scientific and Cultural Organization (UNESCO), Paris. pp. 88-96.

Hernández-Becerril, D. U. \& R. Alonso-Rodríguez. 2004. Study of the marine planktonic dinoflagellate Ceratium divaricatum (Dinophyceae), a confused and considerably variable species. Phycol. Res. 52: 346-354. 
Horiguchi, T. \& R. N. Pienaar. 1986. Ultrastructure of a marine dinoflagellate, Peridinium quinquecorne with special reference to its endosymbiotic alga. Electron Micro. Soc. South. Afr. Proc. 16: 107-108.

Horiguchi, T. \& R. N. Pienaar. 1991. Ultrastructure of a marine dinoflagellate, Peridinium quinquecorne Abé (Peridiniales) from South Africa with particular reference to its chrysophyte endosymbiont. Bot. Mar. 34: 123-131.

Horiguchi, T. \& F. B. Sotto. 1994. On the identity of a red-tide dinoflagellate in Maribago Bay, Philippines. Bull. Plankton Soc. Japan 41(2): 166-169.

Horiguchi, T. \& Y. Takano. 2006. Serial replacement of a diatom endosymbiont in the marine dinoflagellate Peridinium quinquecorne (Peridiniales, Dinophyceae). Phycol. Res. 54: 193-200.

Horstmann, U. 1980. Observations on the peculiar diurnal migration of a red tide Dinophyceae in tropical shallow waters. J. Phycol. 16: 481-485.

Lebour, M. V. 1925. The Dinoflagellates of Northern Seas. Marine Biological Association. Plymouth, U.K. 250 pp.

Lewis, J., A. Rochon, M. Ellegaard, P. J. Mudie \& I. Harding. 2001. The cyst-theca relationship of Bitectatodinium tepikiense (Dinophyceae). Eur. J. Phycol. 36: 137-146.

Madariaga, I., E. Orive \& G. T. Boalch. 1989. Primary production in the Gernika Estuary during a summer bloom of the dinoflagellate Peridinium quinquecorne Abé. Bot. Mar. 32: 152-165.

Margalef, R. 1961. Hidrografía y fitoplancton de un área marina de la costa meridional de Puerto Rico. Invest. Pesq. 18: 33-96.

Okolodkov, Y. B. \& I. Gárate-Lizárraga. 2006. An annotated checklist of dinoflagellates (Dinophyceae) from the Mexican Pacific. Acta Bot. Mex. 74: 1-174.

Okolodkov, Y. B., G. Campos-Bautista, I. Gárate-Lizárraga, J. A. G. González-González, M. Hoppenrath \& V. Arenas. 2007. Seasonal changes of benthic and ephiphytic dinoflagellates in the Veracruz reef zone, Gulf of Mexico. Aquat. Microb. Ecol. 47: 223-237.

Pertola, S., M. A. Faust \& H. Kuosa. 2006. Survey on germination and species composition of dinoflagellates from ballast tanks and recent sediments in ports on the South Coast of Finland, North-Eastern Baltic Sea. Mar. Poll. Bull. 52: 900-911.

Popovský, J. \& L. A. Pfiester. 1990. Süswasserflora von Mitteleuropa, Band 6: Dinophyceae (Dinoflagellida). Gustav Fischer Verlag. Jena. Stuttgart. 271 pp.

Shamsudin, L., A. Awang, A. Ambak \& S. Ibrahim. 1996. Dinoflagellate bloom in tropical fish ponds of coastal waters of the South China Sea. Environmental Monitoring and Assessment (Historical Archive) 40: 303-311.

Shen, C., S. C. Liew \& L. K. Kwoh. 2001. Seawifs observation of chlorophyll distribution in regional seas. Paper presented at the 22nd Asian Conference on Remote Sensing, 5-9 November 2001, Singapore. Centre for Remote Imaging, Sensing and Processing (CRISP), National University of Singapore: Singapore Institute of Surveyors and Valuers (SISV): Asian Association on Remote Sensing (AARS).

Spatharis, S., N. P. Dolapsakis, A. Economou-Amilli, G. Tsirtsis \& D. B Danielidis. 2009. Dynamics of potentially harmful microalgae in a confined Mediterranean Gulf Assessing the risk of bloom formation. Harmful Algae 8: 736-743. 
Steidinger, K. A., M. A. Faust \& D. U. Hernández-Becerril. 2009. Dinoflagellates (Dinoflagellata) of the Gulf of Mexico. In: Felder, D. L. \& D. K. Camp (eds.). Gulf of Mexico-Origins, Waters, and Biota. Biodiversity. Texas A\&M Press, College. pp. 131-154.

Trigueros, J. M., A. Ansotegui \& E. Orive. 2000. Remarks on the morphology and ecology of recurrent dinoflagellate species in the Estuary of Urdaibai (Northern Spain). Bot. Mar. 43: 93-103. 